\title{
Groundwater Vulnerability to Pollution in Kasihan District, Bantul Regency, Indonesia
}

\author{
Setyawan Purnama*, Ahmad Cahyadi \\ Departement of Environmental Geography, Faculty of Geography, Universitas Gadjah Mada, Indonesia \\ ") Corresponding Author (e-mail: setyapurna@geo.ugm.ac.id)
}

Received: 31 January 2019/Accepted: 19 September 2019/Published: 27 December 2019

\begin{abstract}
The groundwater vulnerability to pollution refers to the ease with which pollutants reach groundwater and, by extension, the risk of potential contamination. This concept shows the probability of pollution, based on the assumption that the physical environment has varying capacities to prevent the flow of pollutants into the aquifer. This study was designed to predict groundwater vulnerability in Bantul Regency, Special Region of Yogyakarta, Indonesia. Besides processing secondary data, it measured the depth of the phreatic surface and slope, and analyzed groundwater samples. The measurement and sampling points were determined by considering the location of previous infiltration measurements conducted by Purnama in 2017. The groundwater vulnerability to pollution in the study area was analyzed using the SINTACS method, which operates on a numerical system of weights and rating scores. Each research parameter was assigned with a weight value according to the significance of its effect on groundwater contamination; each of its variables was then rated or ranked based on its intrinsic vulnerability to pollution. As a result, the groundwater vulnerability index ranged from 117.0 to 189.9, which according to the criteria of the SINTACS method, fell into the categories of medium to fairly high vulnerability. Areas with medium vulnerability were located in the Sentolo Formation (consisting of limestone and grumusol soil), while those with fairly high vulnerability were identified in the Yogyakarta Formation (volcanic rock and regosol soil). These findings indicate that geological aspects and soil type greatly affect the groundwater vulnerability to pollution in the research area.
\end{abstract}

Keywords: vulnerability, groundwater, Bantul Regency

Abstrak. Kerentanan airtanah terhadap pencemaran merujuk pada kemudahan zat pencemar mencapai airtanah, sehingga airtanah akan tercemar. Konsep ini menunjukkan suatu probabilitas bahwa pencemaran akan terjadi, yang pada prinsipnya mendasarkan pada anggapan bahwa lingkungan fisik dapat mencegah aliran zat pencemar ke dalam akuifer. Tujuan dari penelitian ini adalah untuk memprediksi kerentanan airtanah di daerah penelitian terhadap pencemaran. Untuk mencapai tujuan tersebut, selain mendasarkan dari data sekunder juga dilakukan pengukuran kedalaman muka freatik, kemiringan lereng dan pengambilan sampel airtanah dari sumur observasi. Penentuan lokasi pengukuran dan pengambilan sampel dilakukan dengan mempertimbangkan lokasi pengukuran infiltrasi yang pernah dilakukan oleh Purnama pada Tahun 2017. Untuk melakukan analisis kerentanan airtanah terhadap pencemaran di daerah penelitian dilakukan dengan Metode SINTACS, yang mendasarkan pada sistem numerik berupa bobot dan rating. Bobot ditentukan berdasarkan signifikansi pengaruh parameter terhadap pencemaran airtanah, sedangkan rating ditentukan berdasarkan signifikansi pengaruh variabel dalam masing-masing parameter terhadap pencemaran airtanah. Hasil penelitian menunjukkan bahwa nilai indeks kerentanan airtanah di daerah penelitian berkisar dari 117,0 hingga 189,9, yang dalam kriteria Indeks SINTACS tergolong pada tingkat kerentanan sedang dan agak tinggi. Wilayah yang termasuk tingkat kerentanan sedang umumnya terletak pada Formasi Sentolo yang berbatuan gamping dan 
mempunyai jenis tanah grumusol. Wilayah yang tergolong kelas kerentanan agak tinggi terletak pada Formasi Yogyakarta yang berbatuan vulkanik dan jenis tanah regosol, sehingga aspek geologi dan jenis tanah sangat menentukan tingkat kerentanan airtanah terhadap pencemaran di daerah penelitian.

Kata kunci: kerentanan, airtanah, Kabupaten Bantul

\section{Introduction}

As the 200 scientists and experts of the United Nations Environment Program (UNEP) have predicted, water scarcity is the second major problem after climate change that the worldwide community needs to face in the $21^{\text {st }}$ century, along with deforestation/desertification and water pollution as the third and fourth issues. Beside reduced water quantity and quality, uneven spatial and temporal distributions are also other water-related challenges that need to be addressed (IPCC, 2007; Cahyadi et al., 2016; Dibyosaputro et al., 2016; Suprihatin and Martono, 2016; Rushayati et al., 2017). Solutions include the realization of optimal hydrological conditions, namely sufficient good quality water supply, i.e., within the existing standards or requirements for use, and even distribution (Dragoni and Sukhija, 2008; Taniguchi et al., 2010; Haldorsen et al., 2011; Treidel et al., 2011).

Currently, pollution is being increasingly considered in themanagement of water resources in big cities, following the escalating water problems associated with it. According to Costudio (2011), sources and processes of pollution can be divided into point and non-point sources. Point pollution covers a narrow area and is caused by various activities in the region; for example, leakages from sewer pipes, chemical waste storage, and oil reservoirs. In contrast, non-point pollution covers large areas, such as that due to the use of pesticides or other chemicals in agricultural fields (Hem, 1970; Bianchi \& Harter, 2002).

The groundwater vulnerability to pollution has become a theme which has attracted many researchers, and recently there have been various methods to evaluate it. In principle, many of these methods take into account the condition of the region, data availability, and intended use of water (Civita, 2010). The results of groundwater vulnerability assessment do not mean that pollution is inevitable; instead, they are an indication that the observed area is easily polluted (Al-Amoush et al., 2010).

There are three types of vulnerability assessment, namely index and overlay methods, statistical methods and process-based methods (Zhang et al., 1996; Magiera, 2000). According to Liggett \& Talwar (2009), the index method is the most popular of these because it is easy to implement and requires fewer data. SINTACS is a method of assessing intrinsic groundwater vulnerability based on index and mapping. It was developed by Civita and De Maio (2004) and is suitable for use in relatively narrow areas, such as a particular district.

Kasihan is a district in Bantul Regency, with a periphery that stretches from the southwest to south of the City of Yogyakarta. It has been suffering from the impact of the sprawling development of the city, including population growth, expansion of residential areas, and rapid structural developments. Currently, it has a population density of 29 people per hectare and a population growth rate of $2.53 \%$, which inevitably generates a soaring amount of domestic waste. Moreover, the hydraulic gradient of the groundwater basin causes groundwater, and any pollutants that it carries, to move from the city in the north to the district in the south. Accordingly, the groundwater in Kasihan District has potentially high vulnerability to pollution. For this reason, the study applies SINTACS to estimate the vulnerability of the groundwater to contamination and to analyze the most influential factors in Kasihan District.

\section{Research Methods}

\subsection{Data Collection}

The study used primary data; i.e., phreatic depth, slope and groundwater quality parameters. The phreatic depth and slope measurements and groundwater sampling were conducted in observation wells that were selected by purposive sampling based on the location of the infiltration 
measurements conducted by Purnama (2016). Depth to water table was measured with a measuring tape stretched from ground level to the surface of the water in each well. Surface slopes were determined with an Abney level on the areas surrounding each well. The water samples were collected in sample bottles and then analyzed at the Laboratory of Environmental Hydrology and Climatology, Faculty of Geography, Universitas Gadjah Mada. The laboratory test focused on analyzing one chemical element, namely nitrate $\left(\mathrm{NO}_{3}\right)$.

\subsection{Data Analysis}

The primary data were processed inSINTACS to identify the groundwater vulnerability in the study area. This is a numerical system that operates on parameter weights and rating scores. Each research parameter was given a weight string or value depending on the significance of its effect on groundwater pollution, and each of its variables was assigned a rating score that defined its intrinsic vulnerability to contamination. The groundwater pollution parameter variables and their rating scores are presented in Table 1.

Table 1. Ratings of the SINTACS Index

\begin{tabular}{|c|c|c|c|c|c|c|c|c|c|c|c|c|c|}
\hline \multicolumn{2}{|c|}{$\begin{array}{c}\text { Phreatic Depth } \\
(\mathrm{m})\end{array}$} & \multicolumn{2}{|c|}{$\begin{array}{l}\text { Infiltration } \\
\text { (mm/hour) }\end{array}$} & \multicolumn{2}{|c|}{ Aeration Condition } & \multicolumn{2}{|c|}{ Soil Texture } & \multicolumn{2}{|c|}{ Aquifer Media } & \multicolumn{2}{|c|}{$\begin{array}{l}\text { Hydraulic Conductivity } \\
\text { (m/det) }\end{array}$} & \multicolumn{2}{|c|}{ Slope (\%) } \\
\hline Class & Rating & Class & Rating & Type of Rock & Rating & Texture & Rating & Type of Rock & Rating & Value & Rating & Class & Rating \\
\hline $0.0-2.0$ & 10.0 & $<1$ & 1.0 & $\begin{array}{l}\text { Coarse alluvial } \\
\text { sediment }\end{array}$ & $6-10$ & Clay & $1-1.5$ & $\begin{array}{l}\text { Coarse alluvial } \\
\text { sediment }\end{array}$ & $8-9$ & $3.9 \times 10^{-6}-5.5 \times 10^{-6}$ & 4.5 & $0-2$ & 9.5 \\
\hline $2.0-2.5$ & 9.0 & $1-5$ & 2.0 & $\begin{array}{l}\text { Karst } \\
\text { limestone }\end{array}$ & $8-10$ & $\begin{array}{l}\text { Silty } \\
\text { clay }\end{array}$ & $1.5-2.0$ & Karst limestone & $9-10$ & $5.5 \times 10^{-6}-1.0 \times 10^{-5}$ & 5.0 & $2-4$ & 8.5 \\
\hline $2.5-3.5$ & 8.5 & $5-20$ & 3.0 & $\begin{array}{l}\text { Fractured } \\
\text { limestone }\end{array}$ & $4-8$ & $\begin{array}{l}\text { Loamy } \\
\text { clay }\end{array}$ & $2.0-3.0$ & $\begin{array}{l}\text { Fractured } \\
\text { limestone }\end{array}$ & $6-9$ & $1.0 \times 10^{-5}-1.8 \times 10^{-5}$ & 5.5 & $4-6$ & 7.5 \\
\hline $3.5-4.5$ & 8.0 & $20-65$ & 4.0 & Slit dolomite & $2-5$ & $\begin{array}{l}\text { Silty } \\
\text { loam } \\
\text { clay }\end{array}$ & $3.0-4.0$ & Slit dolomite & $4-7$ & $1.8 \times 10^{-5}-3.0 \times 10^{-5}$ & 6.0 & $6-9$ & 6.5 \\
\hline $4.5-5.0$ & 7.5 & $65-125$ & 5.0 & $\begin{array}{l}\text { Fine-moderate } \\
\text { alluvial } \\
\text { sediment }\end{array}$ & $3-6$ & $\begin{array}{l}\text { Loamy } \\
\text { silt }\end{array}$ & $3.5-4.0$ & $\begin{array}{l}\text { Fine-moderate } \\
\text { alluvial } \\
\text { sediment }\end{array}$ & $6-8$ & $3.0 \times 10^{-5}-5.0 \times 10^{-5}$ & 6.5 & $9-12$ & 5.5 \\
\hline $5.0-6.0$ & 7.0 & $125-250$ & 6.0 & Sand & $4-7$ & Loam & $4.0-5.0$ & Sand & $7-9$ & $5.0 \times 10^{-5}-9.0 \times 10^{-5}$ & 7.0 & $12-15$ & 4.5 \\
\hline $6.0-7.0$ & 6.5 & $>250$ & 7.0 & $\begin{array}{l}\text { Sandstone, } \\
\text { conglomerate }\end{array}$ & $5-8$ & $\begin{array}{l}\text { Sandy } \\
\text { loam } \\
\text { clay }\end{array}$ & $4.5-5.0$ & $\begin{array}{l}\text { Sandstone, } \\
\text { conglomerate }\end{array}$ & $4-9$ & $9.0 \times 10^{-5}-1.5 \times 10^{-4}$ & 7.5 & $15-18$ & 3.5 \\
\hline $7.0-8.0$ & 6.0 & & & $\begin{array}{l}\text { Turbiditic } \\
\text { sequences }\end{array}$ & $2-5$ & $\begin{array}{l}\text { Sandy } \\
\text { loam }\end{array}$ & $5.5-6.0$ & $\begin{array}{l}\text { Turbiditic } \\
\text { sequences }\end{array}$ & $5-8$ & $1.5 \times 10^{-4}-2.0 \times 10^{-4}$ & 7.75 & $18-21$ & 2.5 \\
\hline $8.0-9.0$ & 5.5 & & & Slit volcanic & $5-10$ & $\begin{array}{l}\text { Sandy } \\
\text { clay }\end{array}$ & $6.3-7.0$ & Slit volcanic & $8-10$ & $2.0 \times 10^{-4}-3.0 \times 10^{-4}$ & 8.0 & $21-25$ & 1.5 \\
\hline $9.0-10.0$ & 5.0 & & & Marl, claystone & $1-3$ & Peat & $7.5-8.0$ & Marl, claystone & $1-3$ & $3.0 \times 10^{-4}-4.5 \times 10^{-4}$ & 8.25 & $25-30$ & 1.0 \\
\hline $10.0-13.0$ & 4.5 & & & Clay, silt, peat & $1-2$ & $\begin{array}{l}\text { Sandy } \\
\text { silt }\end{array}$ & $8.0-8.5$ & Clay, silt, peat & $1-3$ & $4.5 \times 10^{-4}-6.0 \times 10^{-4}$ & 8.5 & & \\
\hline $13.0-17.0$ & 4.0 & & & $\begin{array}{l}\text { Pyroclastic } \\
\text { rock }\end{array}$ & $2-5$ & $\begin{array}{l}\text { Fine } \\
\text { sand }\end{array}$ & $9.0-9.5$ & $\begin{array}{l}\text { Pyroclastic } \\
\text { rock }\end{array}$ & $4-8$ & $6.0 \times 10^{-4}-1.0 \times 10^{-3}$ & 8.75 & & \\
\hline $17.0-20.0$ & 3.5 & & & $\begin{array}{l}\text { Slit } \\
\text { metamorphose }\end{array}$ & $2-6$ & $\begin{array}{l}\text { Fine } \\
\text { gravel }\end{array}$ & $9.5-10.0$ & $\begin{array}{l}\text { Slit } \\
\text { metamorphose }\end{array}$ & $2-5$ & $1.0 \times 10^{-3}-1.5 \times 10^{-3}$ & 9.0 & & \\
\hline $20.0-25.0$ & 3.0 & & & & & $\begin{array}{l}\text { Thin } \\
\text { soil }\end{array}$ & 10.0 & & & $1.5 \times 10^{-3}-2.5 \times 10^{-3}$ & 9.25 & & \\
\hline $25.0-30.0$ & 2.5 & & & & & & & & & $2.5 \times 10^{-3}-4.5 \times 10^{-3}$ & 9.5 & & \\
\hline $30.0-40.0$ & 2.0 & & & & & & & & & $4.5 \times 10^{-3}-4.0 \times 10^{-2}$ & 9.75 & & \\
\hline$>40.0$ & 1.5 & & & & & & & & & & & & \\
\hline
\end{tabular}


Table 2. Weighting scenarios in SINTACS

\begin{tabular}{lccccccc}
\hline \multicolumn{1}{c}{ Weighting Scenario } & S & I & N & T & A & C & S \\
\hline Normal impact & 5 & 4 & 5 & 3 & 3 & 3 & 3 \\
Relevant impact & 5 & 5 & 4 & 5 & 3 & 2 & 2 \\
Drainage from surficial network & 4 & 4 & 4 & 2 & 5 & 5 & 2 \\
Karst impact & 2 & 5 & 1 & 3 & 5 & 5 & 5 \\
Fissured impact & 3 & 3 & 3 & 4 & 4 & 5 & 4 \\
\hline
\end{tabular}

Source: Civita \& De Maio (2004).

Table 3. Groundwater vulnerability index

\begin{tabular}{cc}
\hline Interval of Vulnerability Index & Vulnerability Level \\
\hline$<80$ & Very Low \\
$80-<105$ & Low \\
$105-<140$ & Medium \\
$140-<186$ & Rather High \\
$186-210$ & High \\
$>210$ & Very High \\
\hline
\end{tabular}

Sources: Civita and De Maio (2004), Al Kuisi et al. (2006).

The SINTACS index was calculated from the weighted parameters and ranked or rated variables using equation 1 :

$\mathrm{I}_{\text {SINTACS }}=\sum_{\mathrm{i}=1}^{7} \mathrm{Ri} \times \mathrm{Wi}$

where $\mathrm{I}_{\text {SINTACS }}$ is the groundwater vulnerability index, $\mathrm{R}$ is the rating of each variable in each parameter, and $\mathrm{W}$ is the weight of each parameter, as shown in Table 2.

A normal impact scenario was used to represent the research location, which had two primary sources of contaminants, residential areas and agricultural practices characterised by the application of fertilizers. The calculation of weights and rating scores produced a groundwater vulnerability index, as presented in Table 3. Subsequently, this index was tested for its validity or representativeness of the real conditions in the field by collecting groundwater samples from each observation well and analyzing the nitrate concentration of each of these in the laboratory.

\section{Results and Discussion}

\subsection{Location}

Kasihan District is located at $114^{\circ} 22^{\prime} 24^{\prime \prime}$ $114^{\circ} 24^{\prime} 45^{\prime \prime} \mathrm{E}$ and $7^{\circ} 42^{\prime} 20^{\prime \prime}-7^{\circ} 45^{\prime} 24^{\prime \prime} \mathrm{S}$. Administratively, it covers 3,238 ha and consists of four villages, namely Bangunjiwo (1,543 ha), Tirtonirmolo (513 ha), Tamantirto (672 ha) and Ngestiharjo (510 ha). It is bordered by Godean and Gamping Districts to the north, Bantul District to the south, Sewon District and Yogyakarta City to the east, and Pajangan District to the west.

\subsection{Geology, Soil and Hydrogeology}

Based on the geological map compiled by Rahardjo et al. (1995) there are two rock formations in Bantul, Kasihan District, namely the Yogyakarta Formation (volcanic rock) and the Sentolo Formation (limestone). According to Purnama (2013), the district also has two types of soil, which according to the Bogor LPT soil classification are regosol and grumusol (Figure 1). 


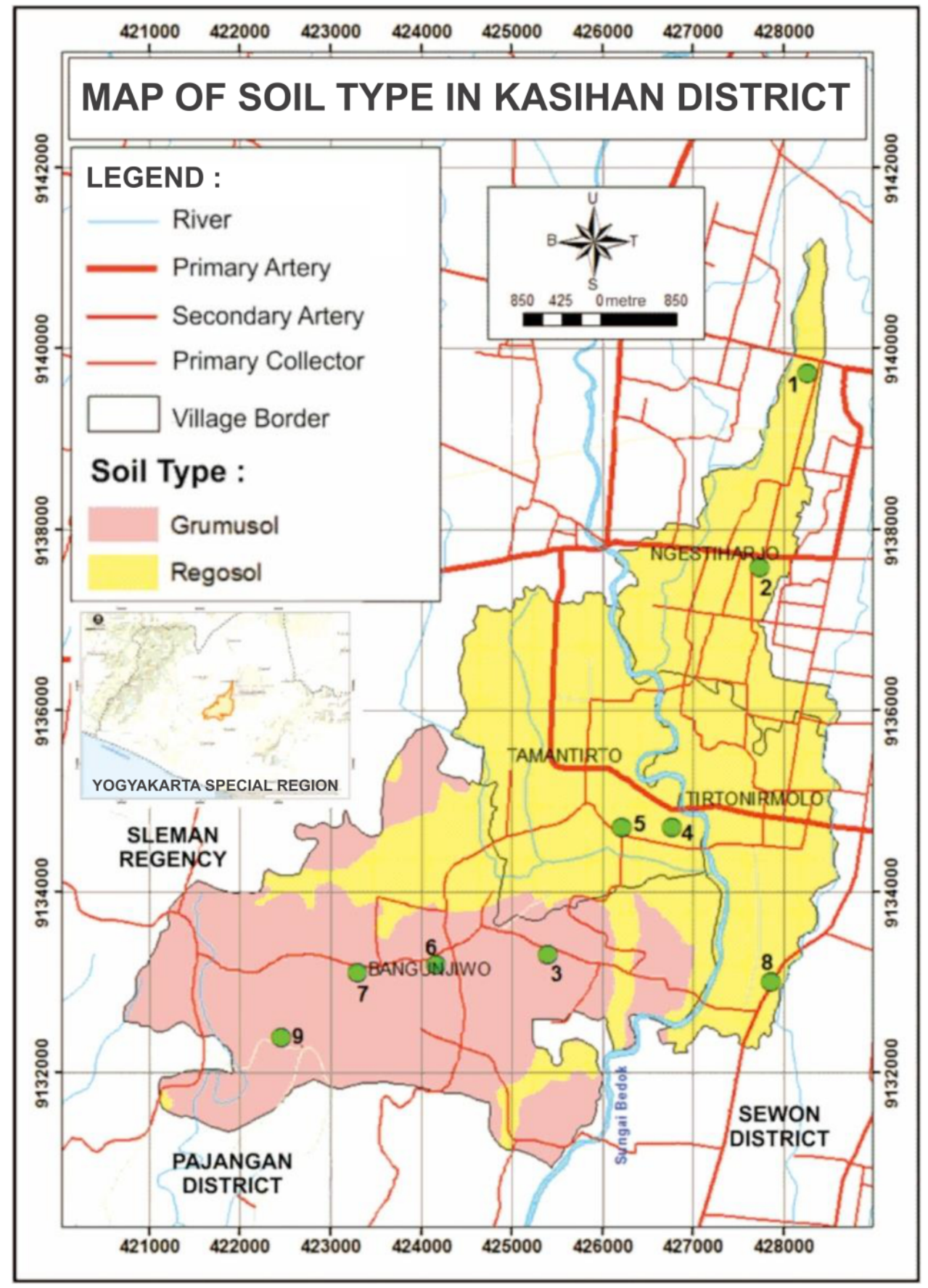

Figure 1. Soil Map of Kasihan District

Previous research by the Faculty of Geography, Universitas Gadjah Mada (2014) suggests that the eastern and northern parts of Kasihan District belong to the Merapi Aquifer System (MAS) or Yogyakarta Formation (Qa), which is a multilayered aquifer that has relatively homogeneous and interconnected hydraulic properties, transmissivity ranging from $894-1,400 \mathrm{~m}^{2} /$ day, and specific yields of $22-28.8 \%$. The groundwater in this aquifer system flows to the south with increasingly smaller hydraulic gradients. Compared to the city in the north, the district has thinner aquifer layers owing to the limestone outcrops in the Sentolo Formation (the base of the Yogyakarta Formation) (Figure 2). 


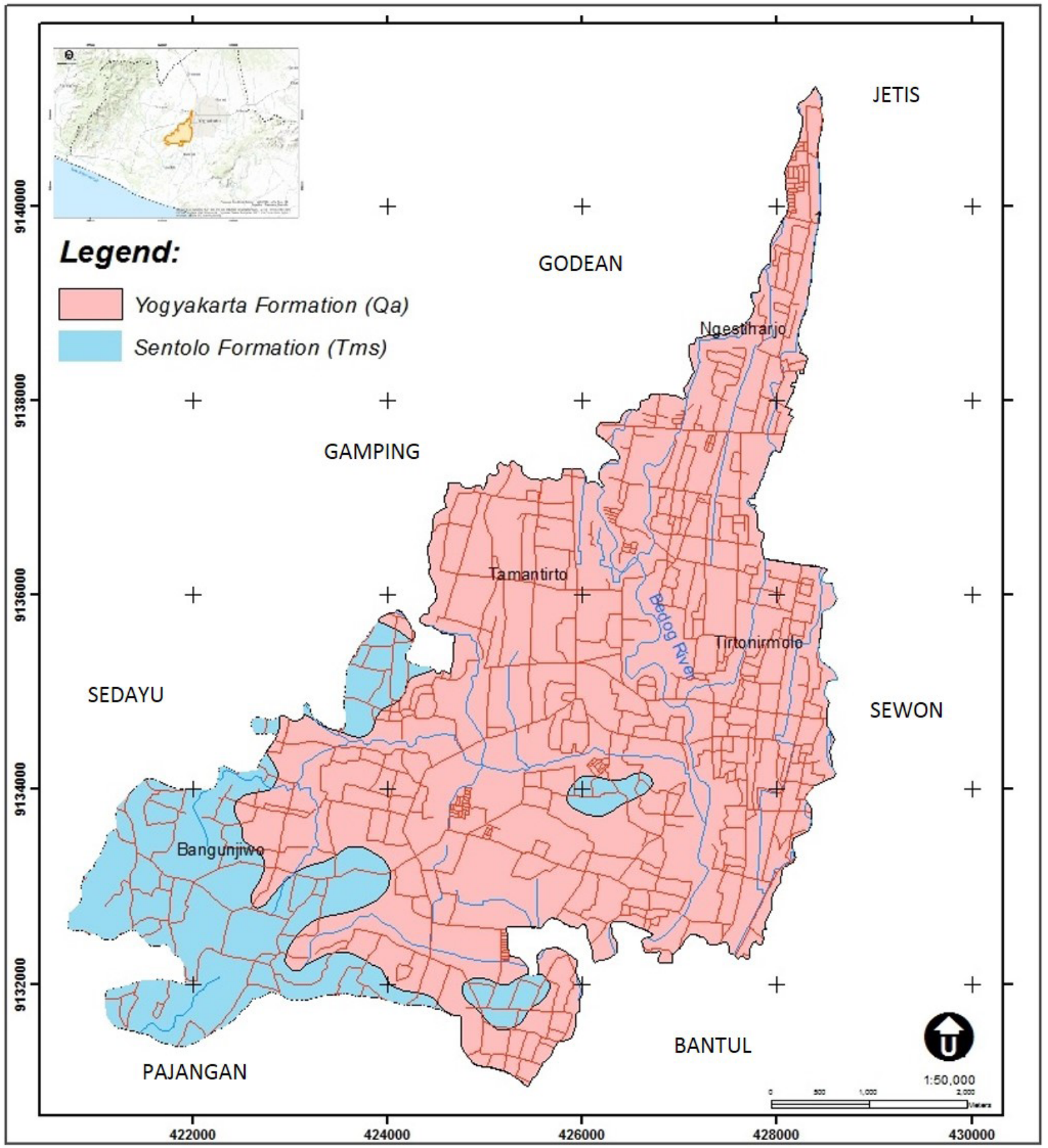

Figure 2. Geological Map of Kasihan District

\subsection{Groundwater Vulnerability to Pollution}

The groundwater vulnerability to pollution refers to the ease with which pollutants reach the groundwater and, by extension, the risk of potential contamination. This concept shows a probability of pollution, which, in principle, is based on the assumption that physical environments can intrinsically prevent the flow of pollutants into the aquifer. Groundwater vulnerability is commonly expressed in an index or presented on a map, which can be used to identify areas that are threatened by pollution. According to Al-Kuisi et al. (2006), prevention of contamination is one aspect of groundwater management.

SINTACS is a modification of DRASTIC, a method to predict groundwater vulnerability to pollution. According to Civita and De Maio (2004), SINTACS is an abbreviation for seven parameters (in Italian) representing environmental settings that define the intrinsic 
groundwater vulnerability to pollution, namely S for Soggiacenza (lit. depth to water table), I for Infiltrazione (a constant infiltration rate), $\mathrm{N}$ for Non saturo (the condition of an aeration zone), $\mathrm{T}$ for Tipologia della copertura (soil texture), A for Acquifero (aquifer media), C for Conducibilità (hydraulic conductivity), and S for Superficie topografica (topography/ slope). The calculated parameters of the SINTACS index in the study area are shown in Table 4.

The depth to water table determines the distance between the ground and the surface of the groundwater. This distance controls the time pollutants need to travel to the groundwater. Because the research subject is unconfined aquifers, depth to water tables indicate phreatic depth from the ground level.
In SINTACS, the deeper the phreatic zone, the lower the rating score. Measurements in the field indicated that the phreatic depth ranged from $4.64 \mathrm{~m}$ to $12.47 \mathrm{~m}$, hence the assigned rating scores were 4.5 to 7.5 .

The infiltration rate regulates the ease of contaminant absorption into the soil, and from the soil surface to the aquifer. A low rate of infiltration means that pollutants cannot easily reach the groundwater. In contrast, a fast rate allows pollutants to seep through soils and reach the groundwater without significant obstacles or delay. In this study, the constant infiltration rate was based on the infiltration data used in Purnama et al. (2013). The results show that this rate varied between 6 and $732 \mathrm{~mm} /$ hour, meaning the rating scores were between 3 and 7 .

Table 4. Calculation of the SINTACS index and vulnerability classes

\begin{tabular}{|c|c|c|c|c|c|c|c|c|c|c|c|c|c|c|}
\hline \multirow{2}{*}{$\begin{array}{c}\text { No. of } \\
\text { Well }\end{array}$} & \multicolumn{2}{|c|}{$\begin{array}{c}\text { Depth of } \\
\text { Phreatic }(\mathrm{m})\end{array}$} & \multicolumn{2}{|c|}{$\begin{array}{l}\text { Infiltration } \\
\text { (mm/hour) }\end{array}$} & \multicolumn{2}{|c|}{$\begin{array}{l}\text { Aeration } \\
\text { Condition }\end{array}$} & \multicolumn{2}{|c|}{ Soil Texture } & \multicolumn{2}{|c|}{ Aquifer Media } & \multicolumn{2}{|c|}{$\begin{array}{l}\text { Hydraulic Con- } \\
\text { ductivity (m/s) }\end{array}$} & \multicolumn{2}{|c|}{ Slope } \\
\hline & Depth & Rating & Inf. & $\begin{array}{l}\text { Rat- } \\
\text { ing }\end{array}$ & Type & Rating & Soil Texture & Rating & Type & Rating & Value & Rating & Class & Rating \\
\hline 1 & 8.29 & 5.5 & 132 & 6 & Sand & 5.5 & Sandy clay & 6.6 & Sand & 8 & $1.4 \times 10^{-4}$ & 7.5 & 0.00 & 9.5 \\
\hline 2 & 7.08 & 6 & 12 & 3 & Sand & 5.5 & Sandy clay & 6.6 & Sand & 8 & $1.4 \times 10^{-4}$ & 7.5 & 0.00 & 9.5 \\
\hline 3 & 4.53 & 7.5 & 6 & 3 & Clay & 1.5 & Silty loam clay & 3.5 & $\begin{array}{l}\text { Fractured } \\
\text { limestone }\end{array}$ & 7.5 & $1.1 \times 10^{-5}$ & 5.5 & 4.44 & 7.5 \\
\hline 4 & 10.10 & 4.5 & 228 & 6 & Sand & 5.5 & Sandy clay & 6.6 & Sand & 8 & $1.4 \times 10^{-4}$ & 7.5 & 0.00 & 9.5 \\
\hline 5 & 8.36 & 5.5 & 732 & 7 & Sand & 5.5 & Fine sand & 9.3 & Sand & 8 & $1.4 \times 10^{-4}$ & 7.5 & 0.00 & 9.5 \\
\hline 6 & 7.23 & 6 & 48 & 4 & Clay & 1.5 & Silty loam clay & 3.5 & $\begin{array}{l}\text { Fractured } \\
\text { limestone }\end{array}$ & 7.5 & $1.1 \times 10^{-5}$ & 5.5 & 2.22 & 8.5 \\
\hline 7 & 12.47 & 4.5 & 6 & 3 & Clay & 1.5 & Silty loam clay & 3.5 & $\begin{array}{l}\text { Fractured } \\
\text { limestone }\end{array}$ & 7.5 & $1.1 \times 10^{-5}$ & 5.5 & 2.22 & 8.5 \\
\hline 8 & 4.97 & 7.5 & 108 & 5 & Sand & 5.5 & Sandy clay & 6.6 & Sand & 8 & $1.4 \times 10^{-4}$ & 7.5 & 0.00 & 9.5 \\
\hline 9 & 4.64 & 7.5 & 24 & 4 & Clay & 1.5 & Silty loam clay & 3.5 & $\begin{array}{l}\text { Fractured } \\
\text { limestone }\end{array}$ & 7.5 & $1.1 \times 10^{-5}$ & 5.5 & 6.67 & 6.5 \\
\hline
\end{tabular}


An aeration zone is a hydrogeological system functioning as a barrier to pollutants in impermeable layers. Clay is impermeable; in other words, it can prevent the flow of contaminants. For this reason, it had a low rating score. Meanwhile, sand is porous and was therefore assigned a high score. Based on the observation results in the field, the study area is composed of sand and clay. The Yogyakarta Formation (volcanic rock) has a sandy texture, while the Sentolo Formation (limestone) has a clay texture. In SINTACS, sand-textured materials were rated 5.5 , whereas clays were 1.5 .

Unconsolidated materials are usually classified by size and distribution. Most systems are based on particle size or grain. Soil texture is a combination of sand, silt and clay content, meaning that it is controlled by the percentage of these three elements. It regulates the ease with which water and pollutants, if any, pass through the soil layers. The study area has various soil textures, namely sandy clay, silt clay and fine sand. Accordingly, the assigned rating scores were 6.6, 3.5 and 9.3.

Aquifer media play a role in determining the rate at which the pollutants mix with groundwater (Tamod et al., 2016). Within an aquifer, several chemical processes occur, such as dissolution and pollutant-rock interaction. There are two types of aquifer in the study area, namely fractured sand and limestone, with rating scores of 8 and 7.5 respectively.

Hydraulic conductivity measures the ability of rocks or soils to transmit fluid (Fetter, 1988; Wanielista et al.,1997; Rushton, 2003; Todd \& Mays, 2005; Davie, 2008). High hydraulic conductivity means that contaminants can flow more quickly than in rock materials with low hydraulic conductivity. Compared with other rocks, sands have higher hydraulic conductivity and consequently high rating scores. The research area is composed of sand and limestone material; therefore, the rating scores in SINTACS were 7.5 and 5.5.

Slope gradient plays a vital role in accelerating or decelerating the flow of contaminants into the ground. A steep slope makes pollutants flow rapidly and allows only a few of them to infiltrate into the soil. Conversely, a flat slope makes fluid flow at a slow rate, giving the pollutants a prolonged chance to infiltrate. Therefore, steep slopes were assigned with low rating scores, whereas gently sloping terrain had high rating scores. The topographic conditions in the study area are widely diverse, from flat to undulating, so the rating scores also varied considerably, from 6.5 to 9.5 .

\subsection{SINTACS Index Analysis}

Because each parameter has different effects on pollution, their assigned weights are not equal. For normal impact scenarios, phreatic depth had a weight of 4 and aeration 5, while soil texture, aquifer media, hydraulic conductivity, and slope were each assigned with a weight value of 3 . Furthermore, the groundwater vulnerability index for each of the nine measurement and observation points was calculated using the rating scores and weights of the research parameters (Table 5). The results show a variation in the groundwater vulnerability index, from 117.0 to 189.9 . Four locations were classified as having medium vulnerability, while the other five areas fell into the category of fairly high vulnerability. This information was processed into the Map of Groundwater Vulnerability to Pollution (Figure 3). The results are consistent with AlShatnawi et al. (2016), who found that areas with medium vulnerability to pollution had a SINTACS index of 97-128.

However, the effects of depth to water table on groundwater vulnerability pollution in this study differ from the results of Al Kuisi et al. (2006), who suggested that high vulnerability was attributable to shallow water depth, i.e., from a few meters to $10 \mathrm{~m}$ below the ground, and a high rate of recharge. In Kasihan District, the depth to water table did not exhibit any correlations with groundwater vulnerability. Nevertheless, the results of this study are in line with those of Leal et al. (2012), which proved that high vulnerability values were associated with a high pollution source index. 
Table 5. Weighted SINTACS parameters (normal impact scenario)

\begin{tabular}{cccccccccc}
\hline No. & $\begin{array}{c}\text { S } \\
\text { (weight 5) }\end{array}$ & $\begin{array}{c}\text { I } \\
\text { (weight 4) }\end{array}$ & $\begin{array}{c}\text { N } \\
\text { (weight 5) }\end{array}$ & $\begin{array}{c}\text { T } \\
\text { (weight 3) }\end{array}$ & $\begin{array}{c}\text { A } \\
\text { (weight 3) }\end{array}$ & $\begin{array}{c}\text { C } \\
\text { (weight 3) }\end{array}$ & $\begin{array}{c}\text { S } \\
\text { (weight 3) }\end{array}$ & $\begin{array}{c}\text { Vulnerability } \\
\text { Index }\end{array}$ & $\begin{array}{c}\text { Vulnerability } \\
\text { Level }\end{array}$ \\
\hline 1 & 27.5 & 24 & 27.5 & 19.8 & 24 & 22.5 & 28.5 & 173.8 & Fairly high \\
2 & 30 & 12 & 27.5 & 19.8 & 24 & 22.5 & 28.5 & 164.3 & Fairly high \\
3 & 37.5 & 12 & 7.5 & 10.5 & 22.5 & 16.5 & 22.5 & 129.0 & Medium \\
4 & 22.5 & 24 & 27.5 & 19.8 & 24 & 22.5 & 28.5 & 168.8 & Fairly high \\
5 & 27.5 & 28 & 27.5 & 27.9 & 24 & 22.5 & 28.5 & 185.9 & Fairly high \\
6 & 30 & 16 & 7.5 & 10.5 & 22.5 & 16.5 & 25.5 & 128.5 & Medium \\
7 & 22.5 & 12 & 7.5 & 10.5 & 22.5 & 16.5 & 25.5 & 117.0 & Medium \\
8 & 37.5 & 20 & 27.5 & 19.8 & 24 & 22.5 & 28.5 & 179.8 & Fairly high \\
9 & 37.5 & 16 & 7.5 & 10.5 & 22.5 & 16.5 & 19.5 & 130.0 & Medium \\
\hline
\end{tabular}

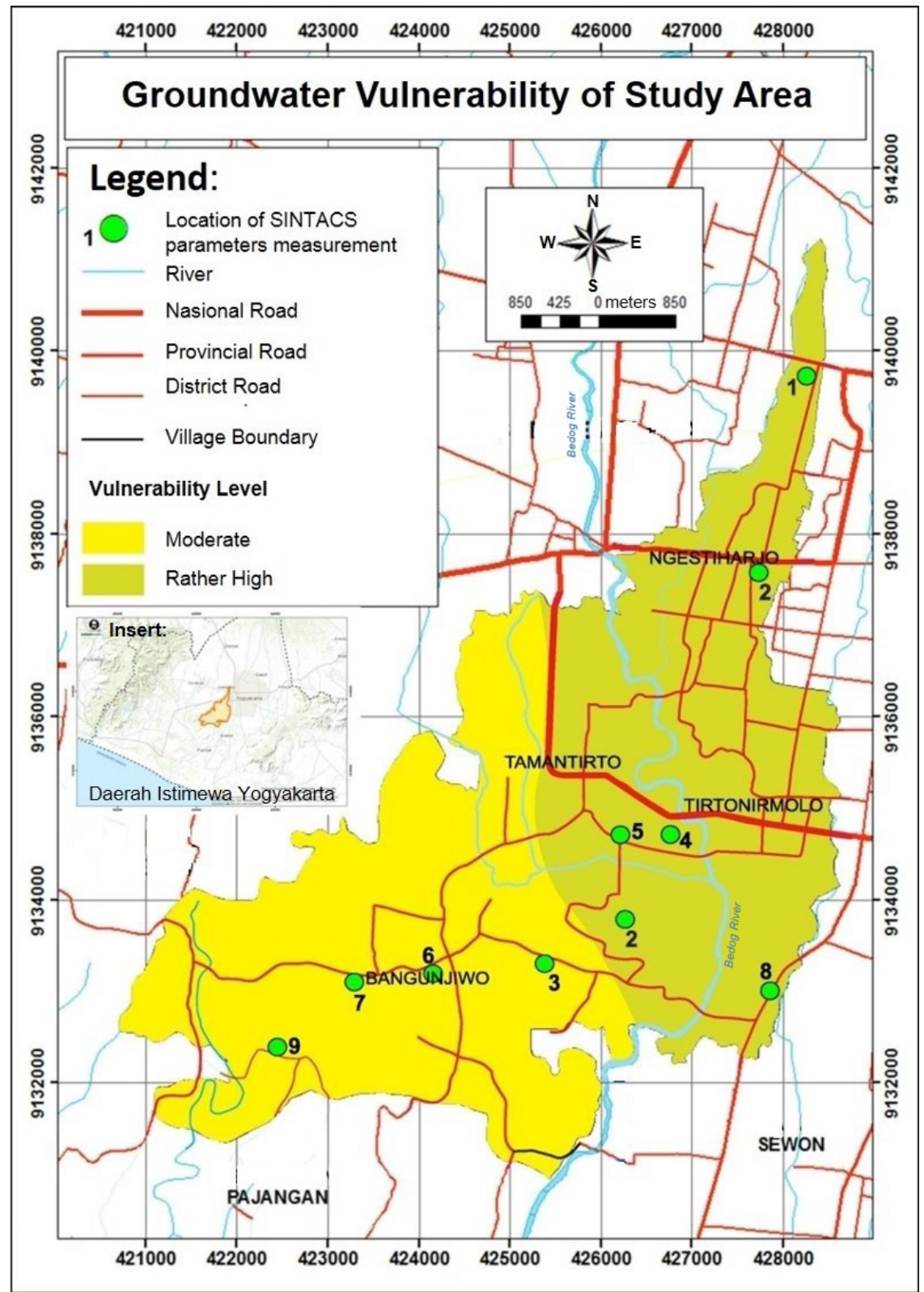

Figure 3. Map of groundwater vulnerability to pollution in the study area 
Figure 3 shows that areas with medium groundwater vulnerability are located in the Sentolo Formation, which is composed of limestone and has grumusol soils. In addition, fairly high vulnerability can be found in the Yogyakarta Formation, with volcanic rock and regosol soils. In other words, geology and soil significantly determine the level of groundwater vulnerability to pollution in the study area.

\subsection{Validation of the Calculation and Analysis Results}

The results of the groundwater vulnerability calculations were validated with the actual conditions in the study area by comparing them with the measured nitrate concentrations, as shown in Table 6 . Based on the laboratory analysis results, the nitrate content in all nine groundwater samples was still within the standards for drinking water quality, varying between $0.43 \mathrm{mg} / \mathrm{l}$ (the lowest) and $6.64 \mathrm{mg} / 1$ (the highest). Considering the distribution, high nitrate concentrations were generally found in locations with fairly high groundwater vulnerability to pollution. Conversely, low concentrations were detected in regions with medium vulnerability. As a conclusion, the groundwater vulnerability to pollution in the study area correlates with the conditions in the field.

These findings are similar to the results of previous studies. Using a modified SINTACS with an additional parameter, land use layers, Noori et al. (2019) found the strongest correlation between nitrate and the vulnerability index (coefficient of determination $=0.75$ ). In Majandang and Sarapirome (2013), the level of nitrate in groundwater was proven to have a significant positive correlation with the vulnerability level (0.51). In addition, Al-Amoush et al. (2010) confirmed that high to very high groundwater vulnerability values were associated with high nitrate levels.

Table 6. Validation of SINTACS values with nitrate concentration

\begin{tabular}{|c|c|c|c|}
\hline No. & Vulnerability Index & Vulnerability Level & Nitrate Concentration $(\mathrm{mg} / \mathrm{l})$ \\
\hline 1 & 173.8 & Fairly high & 2.04 \\
\hline 2 & 164.3 & Fairly high & 6.64 \\
\hline 3 & 129.0 & Medium & 0.78 \\
\hline 4 & 168.8 & Fairly high & 0.8 \\
\hline 5 & 185.9 & Fairly high & 1.0 \\
\hline 6 & 128.5 & Medium & 0.47 \\
\hline 7 & 117.0 & Medium & 0.63 \\
\hline 8 & 179.8 & Fairly high & 0.43 \\
\hline 9 & 130.0 & Medium & 1.17 \\
\hline
\end{tabular}




\section{Conclusion}

The groundwater vulnerability index in the study area ranged between 117.0 and 185.9, with medium vulnerability in four observation sites and fairly high vulnerability in the other five locations. The former can be found in the Sentolo Formation (limestone; grumusol soil), while the latter is located in the Yogyakarta Formation (volcanic rock; regosol soil). For this reason, geology and soil type are believed to be the factors that significantly shape groundwater vulnerability to pollution in the study area. Regarding the SINTACS method, the study has proven that it is suitable for areas with different topographic and geological features that provide a wider alternative for analysis.

\section{Acknowledgments}

This paper is part of a study entitled "Utilization of SINTACS Methods in Predicting Groundwater Vulnerability in Kasihan District, Bantul Regency", financed by the Legal Aid Funding for State Universities, Faculty of Geography, Universitas Gadjah Mada. Sincere gratitude is extended to the Dean for the opportunity provided and for financial assistance.

\section{References}

Al-Amoush, H., Hammouri, N. A., Zunic, F., \& Salameh, E. (2010). Intrinsic vulnerability assessment for the alluvial aquifer in the northern part of Jordan valley. Water resources management, 24(13), 3461-3485.

Al Kuisi, M., El-Naqa, A., \& Hammouri, N. (2006). Vulnerability mapping of shallow groundwater aquifer using SINTACS model in the Jordan Valley area, Jordan. Environmental Geology, 50(5), 651-667.

Al-Shatnawi, A. M., El-Bashir, M. S., Khalaf, R. M. B., \& Gazzaz, N. M. (2016). Vulnerability mapping of groundwater aquifer using SINTACS in Wadi Al-Waleh Catchment, Jordan. Arabian Journal of Geosciences, 9(1), 67.

Bianchi, M., \& Harter, T. (2002). Nonpoint Sources of Pollution in Irrigated Agriculture: Farm Water Quality Planning Series.

Cahyadi, A., Riyanto, I.A., Nurrohmah, H. \& Pramanda, T. (2016). Estimasi Dampak Perubahan Iklim terhadap Imbuhan Airtanah di DAS Progo (Estimation of the Impact of Climate Change on Groundwater Recharge in Progo, Watershed) (in Bahasa Indonesia). Research Report. Faculty of Geography, Universitas Gadjah Mada, Yogyakarta.

Civita, M \& De Maio, M. (2004). Assessing and mapping Groundwater Vulnerability to Contamination: The Italian “Combined Approach. Geofisica Internacional, 43: 513-532.

Civita, M. (2010). The Combined Approach When Assesing and mapping Groundwater Vulnerability to Contaminant. Journal of Water Resources and Protection, 2: 14-28.

Costudio, E. (2011). Trends in Groundwater Pollution: Loss of Groundwater Quality and Related Services. Thematic Paper of Groundwater Governance. Dept. of Geo-Engineering and International Centre for Groundwater Hydrology, Technical University of Catalonia, Barcelona.

Davie, T. (2008). Fundamentals of Hydrology. Routledge, Taylor \& Francis Group, London.

Dibyosaputro, S., Cahyadi, A., Nugraha, H. \& Suprayogi, S. (2016). Estimasi Dampak Perubahan Iklim terhadap Kerawanan Banjir Lahar di Kabupaten Magelang, Jawa Tengah (Estimation of Climate Change Impact on Lahar Susceptibility in Magelang, Central Java) (in Indonesian). Proceeding of National Seminar on Geography 2016. Universitas Muhammadiyah Surakarta, Surakarta. 
Dragoni, W., \& Sukhija, B. S. (2008). Climate change and groundwater: a short review. Geological Society, London, Special Publications, 288(1), 1-12.

Faculty of Geography, Universitas Gadjah Mada. (2014). Kajian Kebijakan Pengelolaan Cekungan Airtanah Sleman - Yogyakarta (Kabupaten Sleman, Kota Yogyakarta dan Kabupaten Bantul. Research Report. Yogyakarta: The Regional Secretariat of Yogyakarta Special Province.

Fetter, C. W. (1988). Applied Hydrogeology. Merrill Publishing Company, Columbus-Ohio.

Haldorsen, S., Heim, M., \& van der Ploeg, M. (2011). Impacts of climate change on groundwater in permafrost areas: case study from Svalbard, Norway. In Climate change effects on groundwater resources: a global synthesis of findings and recommendations, IAHInternational Contributions to Hydrogeology. CRC Press.

Hem, J. D. (1970). Study and interpretation of the chemical characteristics of natural water (No. 1473). US Government Printing Office.

IPCC. (2007). The Physical Science Basis - Summary for Policymakers. Contribution of WGI to The Fourth Assessment Report of The Intergovernmental Panel on Climate Change. http:// www.ipcc.ch/ipccreport/ar4-wgl.htm.

Leal, J. A. R., Silva, F. O. T., \& Montes, I. S. (2012). Analysis of aquifer vulnerability and water quality using SINTACS and geographic weighted regression. Environmental earth sciences, 66(8), 2257-2271.

Lee, R. (1990). Hidrologi Hutan. Gadjah Mada University Press, Yogyakarta.

Liggett, J E \& Talwar S. (2009). Groundwater Vulnerability Assessments and Integrated Water Resource Management. Streamline Watershed Management Bulletin 13 (1): 18-29.

Magiera, P. (2000). Methods for Assessing Groundwater Sensitivity to Pollution. Groundwater 5: 103-114.

Majandang, J., \& Sarapirome, S. (2013). Groundwater vulnerability assessment and sensitivity analysis in Nong Rua, Khon Kaen, Thailand, using a GIS-based SINTACS model. Environmental earth sciences, 68(7), 2025-2039.

Noori, R., Ghahremanzadeh, H., Kløve, B., Adamowski, J. F., \& Baghvand, A. (2019). ModifiedDRASTIC, modified-SINTACS and SI methods for groundwater vulnerability assessment in the southern Tehran aquifer. Journal of Environmental Science and Health, Part A, 54(1), 89-100.

Purnama, S., Febriarta, E., Cahyadi, A., Khakhim, N., Ismangil, L., \& Prihatno, H. (2013). Analisis Karakteristik Akuifer Berdasarkan Pendugaan Geolistrik di Pesisir Kabupaten Cilacap Jawa Tengah. Jurnal Geografi, 11(22), 155-165.

Purnama, S. (2013). Analisis Kapasitas Infiltrasi di Kecamatan Kasihan, Kabupaten Bantul. Research Report. Yogyakarta: Faculty of Geography, Universitas Gadjah Mada.

Purnama S. (2016). Water Infiltration into soil and its effect to surface runoff in Subdistrict of Kasihan, Bantul Regency Advances in Social Science, Education and Humanities Research, volume 79.

Rahardjo, W.; Sukandarrumidi; \& Rosidi, H.M.D. (1995). Geological Map of The Yogyakarta Sheet, Java. Bandung: Geological Research and Development Centre.

Rushayati, S. B., Hermawan, R., \& Meilani, R. (2017). Global Warming Mitigation through the Local Action of Environmental Education in the Plantation Area of Palm Oil. Forum Geografi, Vol. 31, No. 1, pp. 148-162. 
Rushton, K. R. (2004). Groundwater hydrology: conceptual and computational models. John Wiley \& Sons.

Supriatin, L. S., \& Martono, M. (2016). Impacts of Climate Change (El Nino, La Nina, and Sea Level) on the Coastal Area of Cilacap Regency. Forum Geografi, Vol. 30, No. 2, pp. 106-111.

Tamod, Z. E., Polii, B., \& Sikome, R. M. (2016). Detection of Ground Water Availability at Buhias Island, Sitaro Regency. Forum Geografi, Vol. 30, No. 1, pp. 45-57.

Taniguchi, M., Shiraki, Y., \& Huang, S. (2010). Effects of global warming and urbanization on surface/subsurface temperature and cherry blooming in Japan. In Groundwater Response to Changing Climate, pp. 59-64.

Todd, D. K., \& Mays, L. W. (2005). Groundwater Hydrology Edition. Welly Inte.

Treidel, H., Martin-Bordes, J. L., \& Gurdak, J. J. (2011). Major science findings, policy recommendations, and future work. In Climate Change Effects on Groundwater Resources (pp. 395-412). CRC Press.

Wanielista, M., Kersten, R., \& Eaglin, R. (1997). Hydrology: Water Quantity and Quality Control. John Wiley and Sons.

Zhang, R., Hamerlinck J D., Glos S P., Munn L. (1996). Determination of Non Point-Source Pollution Using GIS and Numerical Models. Journal of Environmental Quality 25: 411-418. 